\title{
Why Climate Change Makes Riparian Restoration More Important than Ever: Recommendations for Practice and Research
}

\author{
Nathaniel E. Seavy, Thomas Gardali, Gregory H. Golet, F. Thomas Griggs, Christine A. Howell, \\ Rodd Kelsey, Stacy L. Small, Joshua H. Viers and James F. Weigand
}

\begin{abstract}
Over the next century, climate change will dramatically alter natural resource management. Specifically, historical reference conditions may no longer serve as benchmarks for restoration, which may foster a "why bother?" attitude toward ecological restoration. We review the potential role for riparian restoration to prepare ecological systems for the threats posed by climate change. Riparian ecosystems are naturally resilient, provide linear habitat connectivity, link aquatic and terrestrial ecosystems, and create thermal refugia for wildlife: all characteristics that can contribute to ecological adaptation to climate change. Because riparian systems and the projected impacts of climate change are highly variable geographically, there is a pressing need to develop a place-based understanding of climate change threats to riparian ecosystems. Restoration practitioners should consider how they can modify practices to enhance the resilience of riparian ecosystems to climate change. Such modifications may include accelerating the restoration of private lands, participating in water management decisions, and putting the emerging field of restoration genetics into practice.
\end{abstract}

Keywords: California, climate change, genetics, hydrology, restoration, riparian

Tn recent decades, advances in the science and practice of restoring damaged riparian ecosystems have addressed the local and regional threats posed by habitat loss and nonnative species invasions (Bernhardt et al. 2005). While ecological restoration has often emphasized a return to historical reference conditions, this target has been complicated in riparian systems, where flood control and water delivery often result in modifications of natural flows. Today, riparian restoration is further complicated by global climate change (Harris et al. 2006, Battin et al. 2007, Palmer et al. 2008). During the next century, global temperatures are projected to increase by 1.1 to $6.4^{\circ} \mathrm{C}$ (IPCC $2007 \mathrm{a}, 2007 \mathrm{~b}$ ).

Ecological Restoration Vol. 27, No. 3, 2009 ISSN 1522-4740 E-ISSN 1543-4079 (02009 by the Board of Regents of the University of Wisconsin System. Open Access: Creative Commons license by-nc-nd 3.0
Riparian ecosystems will face increases in air and surface water temperatures, alterations in the magnitude and seasonality of precipitation and run-off, and shifts in reproductive phenology and distribution of plants and animals (Meyer et al. 1999, Barnett et al. 2005, Parmesan 2007, Palmer et al. 2008, Rosenzweig et al. 2008). In this context it is now clearer than ever that a return to historical reference conditions will no longer be the benchmark for restoration success (Choi et al. 2008, Seastedt et al. 2008).

Given the uncertainties about future conditions, climate change may cause people to ask "why bother with restoration?" This question has motivated us to reevaluate our work in the science and practice of riparian restoration. Society is becoming aware of the need for mitigation and adaptation to address the adverse impacts of anthropogenic climate change. Mitigation describes actions for reducing greenhouse gas concentrations, for example, by reducing emissions or developing sinks that remove these gasses from the atmosphere (IPCC 2007a). Adaptation refers to actions designed to reduce the vulnerability of natural and societal systems to the effects of climate change (IPCC 2007a). Even if mitigation efforts were to stop the increase in all greenhouse gas emissions, adaptation would remain important because greenhouse gases already in the atmosphere today will continue to cause the climate to change for decades (IPCC 2007b, Solomon et al. 2009).

Climate change adaptation strategies often propose activities that can enhance ecological resilience (Millar et al. 2007, Heller and Zavaleta 2008). Ecological resilience encompasses 1) the amount of disturbance a system can withstand before changing state; 2) the rate at which a system recovers after disturbance; and 3) the way in 

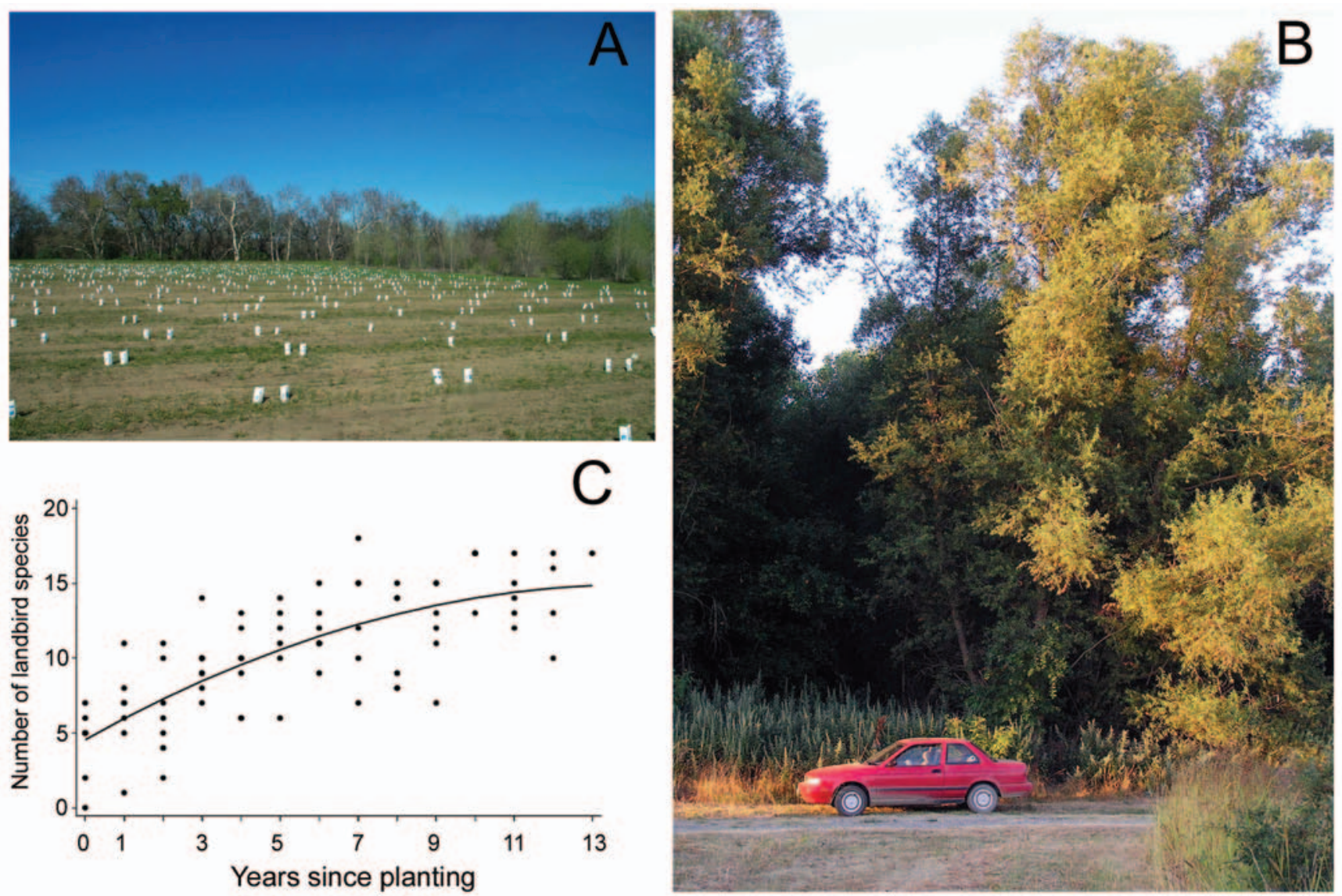

Figure 1. On the Sacramento River in California's Central Valley, horticulture-based restoration can transform open fields (A) to well-established riparian forest (B) in as little as $\mathbf{1 3}$ years. Over this same time, riparian wildlife communities, as measured by such metrics as bird species richness (C) can exhibit dramatic recoveries. Examples like this illustrate the inherent resilience of riparian ecosystems. Images reprinted with permission from Gardali et al. 2006 and Golet et al. 2008

which a system responds to gradual changes (Gunderson 2000, Scheffer et al. 2001). Specific recommendations for enhancing ecological resilience, however, are lacking (Heller and Zavaleta 2008).

Based on general ecological characteristics of riparian systems and our collective experience restoring these ecosystems in California, we suggest that healthy riparian ecosystems promote ecological resilience both within and beyond riparian zones. Here we address 1) how and why riparian restoration prepares ecosystems for climate change; 2) how riparian restoration can be enhanced to accommodate climate change; and 3) research needed to ensure that riparian restoration is robust to climate change.

\section{How and Why Riparian Restoration Prepares Ecosystems for Climate Change}

For forested ecosystems, Millar and others (2007) provide examples of management practices to enhance ecosystem resilience to climate change. These practices include enhancing habitat connectivity, promoting redundancy and buffers, reducing landscape synchrony (by maintaining a mix of successional stages), realigning disrupted conditions, expecting surprises, and identifying and protecting refugia (Millar et al. 2007). Similar recommendations have been made for a wide variety of habitats (Hansen et al. 2003). We use this general framework to review five specific reasons that riparian restoration can enhance ecosystem resilience to climate change.

\section{Natural Resilience of Riparian Systems}

Climate change is projected to lead to increased frequency and severity of extreme weather events, which will likely result in more frequent and severe floods as well as more intense droughts (Easterling et al. 2000). The rate at which ecological systems recover from disturbance will be an important consideration when designing restoration activities. Many riparian plants are adapted to hydrologic and geomorphic disturbances and tolerate both seasonal and annual variation in environmental conditions (Naiman and Decamps 1997). Thus, compared to plants in adjacent upland habitats, riparian species may be more resilient to the increased flooding or drought projected for many regions (Milly et al. 2002, Seager et al. 2007). Restoration programs that reestablish 
appropriate hydrological processes, actively intervene with horticultural techniques to propagate and establish native vegetation where necessary, and manage for genetic diversity to facilitate evolutionary processes can build upon the natural resilience of riparian systems.

The natural resilience of riparian systems is exhibited in the response of riparian wildlife communities to habitat restoration along the Sacramento River in central California (Figure 1). Since European settlement, 95 percent of 324,000 ha of riparian habitat along this river was lost to logging, agriculture, urban development, and flood-control and powergeneration projects (Katibah 1984). In 1988, the Sacramento River Project was launched to coordinate restoration efforts along a $161 \mathrm{~km}$ reach of the Sacramento River between the cities of Red Bluff and Colusa (Golet et al. 2008). A major component of this project was to restore sites previously in agriculture, mostly walnut (Juglans regia) and almond (Prunus dulcis) orchards, by planting local ecotypes of indigenous tree, shrub, and understory species (Alpert et al. 1999). In just ten years, these efforts restored a broad suite of faunal species including both special-status species and the larger native riparian animal community (Gardali et al. 2006, Golet et al. 2008). Consistent with the very high growth rates of floodplain trees, species associated with mature forest, including cavity-nesting birds and crevice-roosting bats, reoccupied restoration sites within a decade (Gardali et al. 2006, Golet et al. 2008).

Of course, there are limits to resilience. Severe human-induced disruptions to these regimes can interrupt important plant and animal population processes. Furthermore, disturbances that are too far out of any given system's natural range of variability (Richter et al. 1997) may lead to the proliferation of disturbance-adapted non-native invasive species (Zedler and Kercher 2004).

\section{Enhancing Connectivity}

Climate change, whether natural or anthropogenic, causes distributional shifts for many organisms. Prioritizing connectivity in landscape planning and reserve design is the most common recommendation for protecting biodiversity from climate change (Heller and Zavaleta 2008). Connectivity is also critical for preserving the ecological processes for evolutionary adaptations to climate change (Cowling and Pressey 2001).

Riverine habitats function as ecological corridors for a wide array of plants and animals (Naiman et al. 1993, Machtans et al. 1996, Hilty and Merenlender 2004). Rivers and riparian vegetation connect highelevation montane areas to sea-level estuaries and oceans. Rivers flow across elevational gradients, linking ecological zones with different climates. Furthermore, tributaries within watersheds provide spatial redundancy that maintains metapopulation and metacommunity dynamics (Collinge et al. 2001). In addition, flowing water moves organic material and energy (Ahearn et al. 2006, Kondolf et al. 2006). Restoring riparian habitats and hydrological function recreates or increases connectivity between habitats and across elevational zones, thus providing avenues for species movements in response to climate change.

\section{Promoting Linkages between Aquatic and Terrestrial Systems}

Riparian zones link riverine and terrestrial systems and make each more ecologically diverse and productive (Naiman and Decamps 1997). Aquatically derived nutrients support luxuriant vegetation and diverse wildlife communities in adjacent upland areas (Merz and Moyle 2006, Uesugi and Murakami 2007). Emerging aquatic insects are prey for birds and bats foraging and breeding in riparian areas (Knopf et al. 1988, Grindal et al. 1999). Equally important are the resources and services that riparian areas convey from terrestrial to aquatic systems. The terrestrial component of riparian vegetation protects water quality by trapping sediment and filtering pollutants through physical and biological processes (National Research Council 2002), and furnishes aquatic food webs with detritus for aquatic invertebrates and terrestrial insect prey for fish (Wipfli 1997). Restoring riparian habitat will strengthen linkages between aquatic and terrestrial systems, making both more resilient and resistant to the stresses imposed by climate change.

In California, the importance of linkages between aquatic and terrestrial systems is exemplified by the Yolo Bypass, an engineered floodplain on the Sacramento River. When the Yolo Bypass floods, 24,000 ha of agricultural land, wetlands, and riparian and upland vegetation are covered with shallow water. The flooding provides important benefits to aquatic, wetland, and terrestrial taxa, including fish and birds (Sommer et al. 2001).

\section{Expanding Thermal Refugia}

Climate change is projected to result in higher air temperatures and, in turn, higher surface water temperatures (Battin et al. 2007, Nelson and Palmer 2007). Because riparian areas have higher water content than surrounding upland areas, they absorb heat and buffer organisms against extreme temperatures (Naiman et al. 2000). During previous periods of climate change, riparian areas served as refugia because they provided microclimates that protected plant biodiversity (Bakker 1984, Meave and Kellman 1994). Riparian vegetation can maintain cooler water temperatures by shading water from sunlight (Sridhar et al. 2004, Cassie 2006) and the infusion of cold groundwater into warmer surface waters creates and maintains pockets of cool water (Chu et al. 2008). Thus, riparian areas provide thermal refugia for animals with thermoregulatory limitations. For example, salmon are able to successfully migrate through high temperature river reaches, but 
only when reaches contain pockets of cooler water (McCullough et al. 2001). Restoring vegetation and protecting groundwater resources will enhance thermal refugia that will be increasingly important as air temperature rises.

\section{Hydrological Benefits}

The projected effects of climate change on hydrologic regimes include increased frequency of extreme flooding events and altered seasonal patterns of precipitation and run-off (Milly et al. 2002, Barnett et al. 2005, Palmer et al. 2008). For example, in California's Central Valley, summer stream flows are projected to decline as annual snowpacks diminish and melt earlier in the spring (Hayhoe et al. 2004, Vicuna and Dracup 2007). Riparian vegetation can promote water infiltration (Brauman et al. 2007) and reduce losses to the ocean as more precipitation falls as rain. However, because riparian vegetation also removes water through evapotranspiration, the net effect of riparian vegetation on water flow is complex. More research on this topic is needed, especially comparing the effects of riparian vegetation on water flows to that of alternative land uses, such as orchards and row crops (Tabacchi et al. 2000).

Restoring riparian ecosystems may also reduce the impacts of extreme flood events. Levees, especially those nearest the river channel, may increase flood stage and flow velocity during floods (Gergel et al. 2002). Riparian restoration to reconnect the river channel with its floodplain by moving back or breaching levees can benefit ecosystem function and nonstructural flood control for urban or agricultural areas (Poff 2002, Golet et al. 2006). The engineered floodplains of the Yolo Bypass on the Sacramento River in California show how restoring ecologically important riparian processes can also provide flood protection for human populations (Sommer et al. 2001). By recharging groundwater and reducing flood damage, riparian restoration will strengthen ecosystem resistance against extreme floods and altered surface flows anticipated from climate change.

\section{Restoration Strategies and Practices That Accommodate Climate Change}

The challenges facing restoration practitioners are not trivial. To meet these challenges, restoration practitioners will need to remain flexible and creative. Novel conditions created by climate change will require that restoration proceeds within the framework of adaptive management, in which specific hypotheses are tested and monitoring is used to verify that desired outcomes are achieved (O'Donnell and Galat 2008). Here, we discuss how specific aspects of on-the-ground restoration activities might be modified to accommodate climate change and to build resilience.

\section{Horticultural Restoration Strategies}

Some horticultural restoration techniques can enhance riparian ecosystem resilience. Techniques under investigation include using ecological genetics to prepare for unexpected conditions (e.g., by deliberately increasing genetic variability) and also planting early seral colonizers adapted to flooding together with late seral species that may be less tolerant of flooding but grow better on drier sites.

Currently, plant materials for restoration are often collected locally, under the assumption that genetically controlled local adaptations are advantageous. When the climate is changing rapidly, planting only local genetic material may not be the most appropriate strategy (Rice and Emery 2003, Bower and Aitken 2008). Collecting seed from within a watershed but across a range of elevations may better facilitate evolutionary adaptation to climate change. Modifying horticultural practices to account for uncertainty is one approach to ensure that riparian restoration is robust to climate change. Planting species that are associated with both ends of the hydrologic spectrum may provide some insurance against unexpected future conditions. Incorporating strategies that address uncertainty into horticultural restoration has the potential to both increase the odds of short-term restoration success and provide long-term maintenance of critical evolutionary processes.

\section{Emphasizing Restoration of Private Lands}

Restoration of private lands will contribute to the connectivity, size, and quality of riparian areas at spatial scales appropriate to the challenges of climate change. Incentive programs for funding, technical assistance, and infrastructure can help private landowners to modify land-use practices and restore native vegetation for conservation (Norton 2000, Langpap 2006). In some cases, state and federal regulations for endangered species may restrict private-lands restoration without innovative incentives. Safe Harbor Agreements can allow landowners to restore habitat for endangered species without legal responsibility for impacts during restoration or to maintain the restored habitat indefinitely (Wilcove and Lee 2004). In California's Central Valley, the U.S. Fish and Wildlife Service and Audubon California have recently established a Safe Harbor Agreement for riparian and wetland restoration projects on private lands in Yolo County. This agreement allows incidental take of federally listed valley elderberry longhorn beetles (Desmocerus californicus dimorphus) and giant garter snakes (Thamnophis gigas) associated with restoration projects that enhance habitat for these species.

Such programs play an essential role in the restoration of riparian ecosystems. Future challenges include adequate funding, economic incentives for agricultural landowners to maintain their land as open space, creating holistic design criteria, and monitoring to ensure that private 
lands restoration enhances ecosystem function and wildlife habitat quality.

\section{Promoting Water and Watershed Management Policies}

While planting riparian vegetation on public and private lands provides many benefits, riparian ecosystems will not fully function with insufficient water. Because climate change is projected to affect water resources for many urban and agricultural uses (Tanaka et al. 2006, Alcamo et al. 2007, Milly et al. 2008), the social and political pressures to modify riparian systems for water storage, transport, and extraction may increase. The ecological stresses of climate change on dammed rivers are projected to be greater than on undammed rivers (Palmer et al. 2008). If societies choose to respond to climate change by building taller levees, deeper wells, and larger dams, riparian ecosystems will be put at greater risk. Restoration practitioners and ecologists must engage with decisionmakers about water management. This engagement will need to include providing information on how changes in water use will influence the outcome of riparian restoration efforts.

Areas of extreme aridity will pose particular challenges, such as in California's Mojave Desert, where groundwater, forced to the surface by tectonic faulting zones, sustains arid riparian plant and animal communities. Urban water use may draw down groundwater below the roots of desert riparian vegetation. Groundwater resources for desert riparian ecosystems are already at risk, particularly at the California-Nevada border, where burgeoning human populations are draining groundwater resources (Bunn et al. 2007). To protect investments in riparian ecosystems, restoration ecologists and water users will need to collaborate to develop policies that ensure that these systems have adequate river flows and groundwater (Boulton and Hancock 2006).
Utility and benefits of water policy complementing riparian restoration are exemplified by work on the Cosumnes River in California. The ecological integrity of this system has been compromised by levees that disrupted hydrological connectivity and by groundwater overdraft resulting in reduced flows (Fleckenstein et al. 2004). This restoration project used engineered levee breaches to restore hydrological connectivity between the floodplain and river channel, which in turn increased aquatic primary production (Ahearn et al. 2006), juvenile salmon recruitment (Jeffres et al. 2008), and geomorphic heterogeneity necessary for riparian establishment and succession (Florsheim and Mount 2002, Trowbridge 2007). However, in order to restore hydrologic connectivity, reduction of upstream groundwater pumping and surface water augmentation is also necessary (Fleckenstein et al. 2004). In addition to providing ecologically important flows to the Cosumnes, this water management approach is also projected to recharge the regional aquifer tapped by two growing urban areas (Fleckenstein et al. 2004).

\section{Riparian Research and Management Priorities for Climate Change}

Research on riparian and hydrologic function spans multiple spatial scales, from the global impacts of climate change on hydrologic patterns to the evolutionary responses of plants and animals to changing climate conditions. We pose several specific research questions for restoring riparian ecosystems in a time of climate change.

How can historic hydrology inform future projections? Recent advances in computing technology allow for new, more robust analyses of the spatial and temporal dimensions of climate change, hydrology, and riparian ecology (Vicuna and Dracup 2007). These approaches use historic information to understand natural variability and the adequacy of climate models for projecting future hydrological conditions. From a nearly 100-year record of daily average flow from the Cosumnes River in California, for example, Booth and colleagues (2006) identified eight types of water-years based on the frequency, magnitude, and duration of hydrological events. This information provides useful historical context for future hydrological conditions.

On a broader scale, climate modeling can provide detailed information about the hydrologic consequences of climate change. Synthetic rainfallrunoff models can aid in understanding how changes in air temperatures influence evapotranspiration potential and surface water runoff. By combining spatial and temporal information, emerging methods will inform practitioners about potential future conditions to improve the planning, design, and implementation of restoration.

Effects of climate change on riparian systems will vary dramatically among river systems (Palmer et al. 2008); thus ecologists, climate modelers, and restoration practitioners need to anticipate consequences of climate change within the context of local ecosystems. This process will be similar to restoring ecosystems in areas where people have disrupted natural fire regimes - a one-size-fits-all solution is impractical. Instead, practitioners will need to draw upon local knowledge of ecosystems and guiding ecological principles to develop appropriate restoration strategies and prescriptions (Fulé 2008).

How can we enhance recruitment of wildlife populations into restored areas? To better respond to rapid environmental shifts accompanying climate change, research on methods to speed recruitment of wildlife into new habitat is needed. Two overarching questions arise: 1) what factors most strongly influence the distribution of a species? and 2) what characteristics promote viable populations in novel habitats? We will need research at the local, reach-level scale, as well as at watershed and multiwatershed 
scales. At the reach level, experimental designs could be developed to determine planting prescriptions or vegetation management that produces desired vegetation composition and structure most rapidly. At the largest scales, research related to effective connectivity (both within the floodplain corridor and extending to upland habitats), landscape matrix, and land use patterns is needed. These smallto-large-scale studies can address the dynamic and unpredictable nature of riparian systems caused by hydrologic regimes and resulting in a dynamic network of seral stages or "mobile habitat mosaics" (Hughes et al. 2005). Research on behavioral mechanisms driving different species' dispersal choices may have an increasingly important role to play in the restoration of wildlife habitat. For example, the use of conspecific attraction-the tendency of individuals of a species to settle near one another-could facilitate the colonization of suitable habitat (reviewed in Ahlering and Faaborg 2006). Similarly, a better understanding of the dispersal and metapopulation dynamics of target species is essential for promoting restoration that improves landscape connectivity for wildlife (Bélisle and St. Clair 2001, Collinge et al. 2001).

How will the phenology of riparian plants and animals respond to climate change? Another ecological challenge of climate change is the loss of synchrony between reproductive phenology and resource availability or natural disturbances (Both and Visser 2001, Inouye 2008). Understanding the physiological tolerances and phenological responses of riparian plants and animals to changes in climate and hydrology will become increasingly important to restoration ecologists. For example, in California's Central Valley, Oregon ash (Fraxinus latifolia) typically breaks bud in midMarch in the northern Sacramento Valley, while on the lower San Joaquin River its buds break on the first of May. This six- to eight-week difference in phenology holds true for seedling germination from both areas as well. Phenological variation may be associated with genetic variation. In European riparian systems, black poplars (Populus nigra) show significant genetic variation among populations, even within catchments (Smulders et al. 2008). Understanding how genetic and environmental differences between the watersheds contribute to phenological variation will help in developing new strategies to restore riparian vegetation in a manner that is robust to climate change (Hufford and Mazer 2003).

\section{Conclusion}

Responding to climate change at the appropriate temporal and spatial scales will require that government agencies, private land owners, and nongovernmental organizations work together to improve water policy, land management, urban development, and many other diverse matters. Governments will be formative in climate change adaptation and the organization of management to transition from adaptation to recovery. However, the speed with which national governments respond to climate change may not match the need for ecological adaptation to climate change. For example, as recently as 2007, the U.S. Department of the Interior was not yet providing guidance to resource managers about how to respond to actual or forecasted climate changes (U.S. General Accountability Office 2007). In the absence of national leadership, smaller-scale governments and nongovernmental organizations may have a large role in guiding management that prepares riparian ecosystems for climate change.

The effects of climate change are already upon us, making it more important than ever for restoration practitioners and researchers to share information effectively and with diverse audiences. Information networks, such as the Global Restoration Network (www.globalrestoration network.org) and the National River
Restoration Science Synthesis (nrrss. nbii.gov), will be important to ensure that the most recent findings and best management practices are shared among those monitoring, managing, and restoring riparian ecosystems. The challenge includes efficiently converting information into knowledge (Roux et al. 2006). Sharing information about restoration and climate change with policymakers and the public is necessary. In an era of rapid environmental change, we need to inform people about the likely threats that climate change poses to ecosystems and society. It is also important to empower people with the knowledge that ecological restoration has the potential to reduce the severity of these threats.

Basic challenges confronting restoration practitioners today will remain important in the future. Invasions of non-native species, facilitated by climate change and movements by people, will continue to occur. Altered hydrological regimes may increase the risk that restoration strategies that worked in the past will fail in the future.

When medical resources are limited, doctors use triage to prioritize the treatment of patients based on the urgency for care and the likelihood that treatment will be successful. In a management context, Millar and colleagues (2007) suggested that such an approach to preparing ecosystems for climate change could be used "to sort management situations into categories according to urgency, sensitivity, and capacity of available resources to achieve desired goals." Given that many riparian systems are highly degraded from a long history of anthropogenic activities (Tockner and Stanford 2002, Zedler and Kercher 2005), we are now faced with a decision about whether to continue investing resources to treat these ecosystems. Functional riparian systems have tremendous potential to reduce the adverse effects of climate change by enhancing ecosystem resilience. To benefit from this capacity, we urgently 
need riparian restoration and the science that guides it.

\section{Acknowledgments}

This manuscript was funded in part by a CALFED Science Fellowship (U-04-SC$005)$ to N.E. Seavy and a grant from the S.D. Bechtel Jr. Foundation. Contributions to the manuscript from PRBO Conservation Science were written at the Palomarin Field Station, which received support from NSF (DBI-0533918). This is PRBO Conservation Science contribution number 1666. Comments from three anonymous reviewers improved this manuscript.

\section{References}

Ahearn, D.S., J.H. Viers, J.F. Mount and R.A. Dahlgren. 2006. Priming the productivity pump: Flood pulse driven trends in suspended algal biomass distribution across a restored floodplain. Freshwater Biology 51:1417-1433.

Ahlering, M.A. and J. Faaborg. 2006. Avian habitat management meets conspecific attraction: If you build it, will they come? Auk 123:301-312.

Alcamo, J., M. Florke and M. Marker. 2007. Future long-term changes in global water resources driven by socioeconomic and climatic changes. Hydrological Sciences Journal 52:247-275.

Alpert, P., F.T. Griggs and D.R. Peterson. 1999. Riparian forest restoration along large rivers: Initial results from the Sacramento River Project. Restoration Ecology 7:360-368.

Bakker, E.S. 1984. An Island Called California: An Ecological Introduction to its Natural Communities. Berkeley: University of California Press.

Barnett, T.P., J.C. Adam and D.P. Lettenmaier. 2005. Potential impacts of a warming climate on water availability in snow-dominated regions. Nature 438:303-309.

Battin, J., M.W. Wiley, M.H. Ruckelshaus, R.N. Palmer, E. Korb et al. 2007. Projected impacts of climate change on salmon habitat restoration. Proceedings of the National Academy of Sciences 104:6720-6725.

Bélisle, M. and C.C. St. Clair. 2001. Cumulative effects of barriers on the movements of forest birds. Ecology \& Society 5(2):9. www.ecologyandsociety.org/ vol5/iss $2 /$ art 9

Bernhardt, E.S., M.A. Palmer, J.D. Allan, G. Alexander, K. Barnas et al. 2005. Syn- thesizing U.S. river restoration efforts. Science 308:636-637.

Booth, E., J. Mount and J.H. Viers. 2006. Hydrologic variability of the Cosumnes River floodplain. San Francisco Estuary \& Watershed Science 4(2):2. repositories .cdlib.org/jmie/sfews/vol4/iss2/art2/

Both, C. and M.E. Visser. 2001. Adjustment to climate change is constrained by arrival date in a long-distance migrant bird. Nature 411:296-298.

Boulton, A.J. and P.J. Hancock. 2006. Rivers as groundwater-dependent ecosystems: A review of degrees of dependency, riverine processes and management implications. Australian Journal of Botany 54:133-144.

Bower, A.D. and S.N. Aitken. 2008. Ecological genetics and seed transfer guidelines for Pinus albicaulis (Pinaceae). American Journal of Botany 95:66-76.

Brauman, K.A., G.C. Daily, T.K. Duarte and H.A. Mooney. 2007. The nature and value of ecosystem services: An overview highlighting hydrologic services. Annual Review of Environment and Resources 32:67-98.

Bunn, D., A. Mummert, M. Hoshovsky, K. Gilardi and S. Shanks. 2007. California wildlife: Conservation challenges; California's wildlife action plan. Sacramento: California Department of Fish and Game.

Cassie, D. 2006. The thermal regime of rivers: A review. Freshwater Biology 51: 1389-1406.

Choi, Y.D., V.M. Temperton, E.B. Allen, A.P. Grootjans, M. Halassy et al. 2008. Ecological restoration for future sustainability in a changing environment. Ecoscience 15:53-64.

Chu, C., N.E. Jones, N.E. Mandrak, A.R. Piggott and C.K. Minns. 2008. The influence of air temperature, groundwater discharge, and climate change on the thermal diversity of stream fishes in southern Ontario watersheds. Canadian Journal of Fisheries and Aquatic Sciences 65:297-308.

Collinge, S.K., M. Holyoak, C.B. Barr and J.T. Marty. 2001. Riparian habitat fragmentation and population persistence of the threatened valley elderberry longhorn beetle in central California. Biological Conservation 100:103-113.

Cowling, R.M. and R.L. Pressey. 2001. Rapid plant diversification: Planning for an evolutionary future. Proceedings of the National Academy of Sciences 98: 5452-5457.

Easterling, D.R., G.A. Meehl, C. Parmesan, S.A. Changnon, T.R. Karl and
L.O. Mearns. 2000. Climate extremes: Observations, modeling, and impacts. Science 289:2068-2074.

Fleckenstein, J., M. Anderson, G. Fogg and J. Mount. 2004. Managing surface water-groundwater to restore fall flows in the Cosumnes River. Journal of Water Resources Planning and Management 130:301-310.

Florsheim, J.L. and J.F. Mount. 2002. Restoration of floodplain topography by sand-splay complex formation in response to intentional levee breaches, Lower Cosumnes River, California. Geomorphology 44:67-94.

Fulé, P.Z. 2008. Does it make sense to restore wildland fire in changing climate? Restoration Ecology 16:526-531.

Gardali, T., A.L. Holmes, S.L. Small, N. Nur, G.R. Geupel and G.H. Golet. 2006. Abundance patterns of landbirds in restored and remnant riparian forests on the Sacramento River, California, USA. Restoration Ecology 14:391-403.

Gergel, S.E., M.D. Dixon and M.G. Turner. 2002. Consequences of human-altered floods: Levees, floods, and floodplain forests along the Wisconsin River. Ecological Applications 12:1755-1770.

Golet, G.H., T. Gardali, C.A. Howell, J. Hunt, R.A. Luster et al. 2008. Wildlife response to riparian restoration on the Sacramento River. San Francisco Estuary \& Watershed Science 6(2):1. repositories .cdlib.org/jmie/sfews/vol6/iss2/art1/

Golet, G.H., M.D. Roberts, R.A. Luster, G. Werner, E.W. Larsen et al. 2006. Assessing societal impacts when planning restoration of large alluvial rivers: A case study of the Sacramento River project, California. Environmental Management 37:862-879.

Grindal, S.D., J.L. Morissette and R.M. Brigham. 1999. Concentration of bat activity in riparian habitats over an elevational gradient. Canadian Journal of Zoology 77:972-977.

Gunderson, L.H. 2000. Ecological resilience-in theory and application. Annual Review of Ecology and Systematics 31:425-439.

Hansen, L.J., J.L. Biringer and J.R. Hoffman, eds. 2003. Buying Time: A User's Manual for Building Resistance and Resilience to Climate Change in Natural Systems. Washington DC: World Wildlife Fund.

Harris, J.A., R.J. Hobbs, E. Higgs and J. Aronson. 2006. Ecological restoration and global climate change. Restoration Ecology 14:170-176. 
Hayhoe, K., D. Cayan, C.B. Field, P.C. Frumhoff, E.P. Maurer et al. 2004. Emissions pathways, climate change, and impacts on California. Proceedings of the National Academy of Sciences 101: $12422-12427$.

Heller, N.E. and E.S. Zavaleta. 2008. Biodiversity management in the face of climate change: A review of 22 years of recommendations. Biological Conservation 142:14-32.

Hilty, J.A. and A.M. Merenlender. 2004. Use of riparian corridors and vineyards by mammalian predators in northern California. Conservation Biology 18: 126-135.

Hufford, K.M. and S.J. Mazer. 2003. Plant ecotypes: Genetic differentiation in the age of ecological restoration. Trends in Ecology \& Evolution 18:147-155.

Hughes, F.M.R., A. Colston and J.O. Mountford. 2005. Restoring riparian ecosystems: The challenge of accommodating variability and designing restoration trajectories. Ecology \& Society 10(1):12. www.ecologyandsociety.org/ vol10/iss1/art12/

Inouye, D.W. 2008. Effects of climate change on phenology, frost damage, and floral abundance of montane wildflowers. Ecology 89:353-362.

Intergovernmental Panel on Climate Change (IPCC). 2007a. Climate Change 2007: Impacts, Adaptation, and Vulnerability. Contribution of Working Group II to the Fourth Assessment Report of the Intergovernmental Panel on Climate Change. New York: Cambridge University Press. 2007b. Climate Change 2007: The Physical Science Basis. Contribution of Working Group I to the Fourth Assessment Report of the Intergovernmental Panel on Climate Change. New York: Cambridge University Press.

Jeffres, C.A., J.J. Opperman and P.B Moyle. 2008. Ephemeral floodplain habitats provide best growth conditions for juvenile Chinook salmon in a California river. Environmental Biology of Fishes 83:449-458.

Katibah, E.F. 1984. A brief history of riparian forests in the Central Valley of California. Pages 23-29 in R.E. Warner and K.M. Hendrix (eds), California Riparian Systems: Ecology, Conservation, and Productive Management. Berkeley: University of California Press.

Knopf, F.L., R.R. Johnson, T. Rich, F.B. Samson and R.C. Szaro. 1988. Conservation of riparian ecosystems in the United States. Wilson Bulletin 100: 272-284.
Kondolf, G.M., A.J. Boulton, S. O’Daniel, G.C. Poole, F.J. Rahel et al. 2006. Process-based ecological river restoration: Visualizing three-dimensional connectivity and dynamic vectors to recover lost-linkages. Ecology \& Society 11(2):5. www.ecologyandsociety.org/vol11/iss $2 /$ $\operatorname{art} 5 /$

Langpap, C. 2006. Conservation of endangered species: Can incentives work for private landowners? Ecological Economics 57:558-572.

Machtans, C.S., M.A. Villard and S.J. Hannon. 1996. Use of riparian buffer strips as movement corridors by forest birds. Conservation Biology 10: 1366-1379.

McCullough, D.A., S. Spalding, D. Sturdevant and M. Hicks. 2001. Summary of technical literature examining the physiological effects of temperature on salmonids: Issue paper 5. U.S. Environmental Protection Agency Report USEPA-910-D-01-005.

Meave, J. and M. Kellman. 1994. Maintenance of rain forest diversity in riparian forests of tropical savannas: Implications for species conservation during Pleistocene drought. Journal of Biogeography 21:121-135.

Merz, J.E. and P.B. Moyle. 2006. Salmon, wildlife, and wine: Marine-derived nutrients in human-dominated ecosystems of central California. Ecological Applications 16:999-1009.

Meyer, J.L., M.J. Sale, P.J. Mulholland and N.L. Poff. 1999. Impacts of climate change on aquatic ecosystem functioning and health. Journal of the American Water Resources Association 35: 1373-1386.

Millar, C.I., N.L. Stephenson and S.L. Stephens. 2007. Climate change and forests of the future: Managing in the face of uncertainty. Ecological Applications 17:2145-2151.

Milly, P.C.D., J. Betancourt, M. Falkenmark, R.M. Hirsch, Z.W. Kundzewicz et al. 2008. Stationarity is dead: Whither water management? Science 319:573-574.

Milly, P.C.D., R.T. Wetherald, K.A. Dunne and T.L. Delworth. 2002. Increasing risk of great floods in a changing climate. Nature 415:514-517.

Naiman, R.J., R.E. Bilby and P.A. Bisson. 2000. Riparian ecology and management in the Pacific coastal rain forest. Bioscience 50:996-1011.

Naiman, R.J. and H. Decamps. 1997. The ecology of interfaces: Riparian zones.
Annual Review of Ecology and Systematics 28:621-658.

Naiman, R.J., H. Decamps and M. Pollock. 1993. The role of riparian corridors in maintaining regional biodiversity. Ecological Applications 3:209-212.

National Research Council. 2002. Riparian Areas: Functions and Strategies for Management. Washington DC: National Academy Press.

Nelson, K.C. and M.A. Palmer. 2007. Stream temperature surges under urbanization and climate change: Data, models, and responses. Journal of the American Water Resources Association 43: 440-452.

Norton, D.A. 2000. Conservation biology and private land: Shifting the focus. Conservation Biology 14:1221.

O'Donnell, T.K. and D.L. Galat. 2008. Evaluating success criteria and project monitoring in river enhancement within an adaptive management framework. Environmental Management 41:90-105.

Palmer, M.A., C.A.R. Liermann, C. Nilsson, M. Florke, J. Alcamo et al. 2008. Climate change and the world's river basins: Anticipating management options. Frontiers in Ecology and the Environment 6: 81-89.

Parmesan, C. 2007. Influences of species, latitudes and methodologies on estimates of phenological response to global warming. Global Change Biology 13:1860-1872.

Poff, N.L. 2002. Ecological response to and management of increased flooding caused by climate change. Philosophical Transactions of the Royal Society of London, Series A 360:1497-1510.

Rice, K.J. and N.C. Emery. 2003. Managing microevolution: Restoration in the face of global change. Frontiers in Ecology and the Environment 1:469-478.

Richter, B., J. Baumgartner, R. Wingington and D. Braun. 1997. How much water does a river need? Freshwater Biology 37:231-249.

Rosenzweig, C., D. Karoly, M. Vicarelli, P. Neofotis, Q. Wu et al. 2008. Attributing physical and biological impacts to anthropogenic climate change. Nature 453:353-357.

Roux, D.J., K.H. Rogers, H.C. Biggs, P.J. Ashton and A. Sergeant. 2006. Bridging the science-management divide: Moving from unidirectional knowledge transfer to knowledge interfacing and sharing. Ecology \& Society 11(1):4. www.ecology andsociety.org/vol11/iss1/art4/

Scheffer, M., S. Carpenter, J.A. Foley, C. Folke and B. Walker. 2001. 
Catastrophic shifts in ecosystems. Nature 413:591-596.

Seager, R., M.F. Ting, I. Held, Y. Kushnir, J. Lu et al. 2007. Model projections of an imminent transition to a more arid climate in southwestern North America. Science 316:1181-1184.

Seastedt, T.R., R.J. Hobbs and K.N. Suding. 2008. Management of novel ecosystems: Are novel approaches required? Frontiers in Ecology and the Environment 6: 547-553.

Smulders, M.J.M., J.E. Cottrell, F. Lefèvre, J. van der Schoot, P. Arens et al. 2008. Structure of the genetic diversity in black poplar (Populus nigra L.) populations across European river systems: Consequences for conservation and restoration. Forest Ecology and Management 255:1388-1399.

Solomon, S., G. Plattner, R. Knutti and P. Friedlingstein. 2009. Irreversible climate change due to carbon dioxide emissions. Proceedings of the National Academy of Sciences 106:1704-1709.

Sommer, T., B. Harrell, M. Nobriga, R. Brown, P. Moyle et al. 2001. California's Yollo Bypass: Evidence that flood control can be compatible with fisheries, wetlands, wildlife, and agriculture. Fisheries 26:6-16.

Sridhar, V., A.L. Sansone, J. LaMarche, T. Dubin and D.P. Lettenmaier. 2004. Prediction of stream temperature in forested watersheds. Journal of the American Water Resources Association 40:197-213.

Tabacchi, E., L. Lambs, H. Guilloy, A.M. Planty-Tabacchi, E. Muller and $\mathrm{H}$. Decamps. 2000. Impacts of riparian vegetation on hydrological processes. Hydrological Processes 14:2959-2976.

Tanaka, S.K., T.J. Zhu, J.R. Lund, R.E. Howitt, M.W. Jenkins et al. 2006. Climate warming and water management adaptation for California. Climatic Change 76:361-387.
Tockner, K. and J.A. Stanford. 2002. Riverine flood plains: Present state and future trends. Environmental Conservation 29: 308-330.

Trowbridge, W.B. 2007. The role of stochasticity and priority effects in floodplain restoration. Ecological Applications 17:1312-1324.

Uesugi, A. and M. Murakami. 2007. Do seasonally fluctuating aquatic subsidies influence the distribution pattern of birds between riparian and upland forests? Ecological Research 22:274-281.

U.S. General Accountability Office. 2007. Climate change: Agencies should develop guidance for addressing the effects on Federal land and water resources. U.S. General Accountability Office Report to Congressional Requesters GAO-07-863.

Vicuna, S. and J.A. Dracup. 2007. The evolution of climate change impact studies on hydrology and water resources in $\mathrm{Cal}-$ ifornia. Climatic Change 82:327-350.

Wilcove, D.S. and J. Lee. 2004. Using economic and regulatory incentives to restore endangered species: Lessons learned from three new programs. Conservation Biology 18:639-645.

Wipfli, M.S. 1997. Terrestrial invertebrates as salmonid prey and nitrogen sources in streams: Contrasting old-growth and young-growth riparian forests in southeastern Alaska, USA. Canadian Journal of Fisheries and Aquatic Sciences 54:1259-1269.

Zedler, J.B. and S. Kercher. 2004. Causes and consequences of invasive plants in wetlands: Opportunities, opportunists, and outcomes. Critical Reviews in Plant Sciences 23:431-452.

2005. Wetland resources: Status, trends, ecosystem services, and restorability. Annual Review of Environment and Resources 30:39-74.
Nathaniel E. Seavy, PRBO Conservation Science, 3820 Cypress Drive \#11, Petaluma, CA 94954, and Information Center for the Environment, Department of Environmental Science \& Policy, University of California, Davis, CA 95616 , nseavy@prbo.org

Thomas Gardali, PRBO Conservation Science, 3820 Cypress Dr \#11, Petaluma, CA 94954

Gregory H. Golet, The Nature Conservancy, 500 Main St, Chico, CA 95928
F. Thomas Griggs, River Partners, 580 Vallombrosa, Chico, CA 95926

Christine A. Howell, PRBO Conservation Science, 3820 Cypress Dr \#11, Petaluma, CA 94954

Rodd Kelsey, Audubon California, Landowner Stewardship Program, 765 University Avenue, Suite 200, Sacramento, CA 95825

Stacy L. Small, Land, Water \& Wildlife Program, Environmental Defense Fund, 1875 Connecticut Ave NW, Washington, DC 20001

Joshua H. Viers, Information Center for the Environment, Department of Environmental Science \& Policy, University of California, Davis, CA 95616

James F. Weigand, Bureau of Land Management, California State Office, 2800 Cottage Way, Rm 1928, Sacramento, CA 95825 